\title{
Анализа ситуације и предвиђања у вези са епидемијом САРС-КоВ-2 вируса у Републици Српској на дан 27. мај 2020.
}

\author{
Димитрије Д. Чвокић ${ }^{1}$
}

\section{Сажетак}

На основу података доступних на званичној страници Владе РС поводом епидемије изазване CAPC-КоВ-2 вирусом, извршена су предвиђања која се тичу завршетка епидемије, процјене

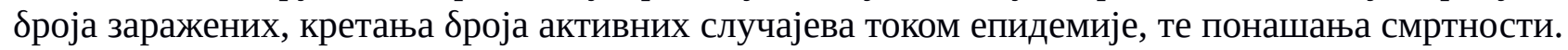
За предвиђања су коришћени оруђе FBprophet и пакети scipy, pandas, и matplotlib. Предвиђања динамике промјена (Time Series Forecasting) су урађена помоћу FBprophet-a, а обрада података и уклапање епидемијске криве помоћу scipy и pandas-a. Визуелизација аналитике је урађена помоћу matplotlib-a. Добијени резултати су детаљно продискутовани.

Кључне ријечи: САРС-КоВ-2, епидемија, Република Српска, Time Series Forecasting, FBprophet, curve fitting

\section{1 Процјена понашања вриједности Rt}

Један од начина за предвиђање када би могао наступити крај епидемије, или бар почетак новог периода за значајно ублажавање епидемиолошких мјера, јесте праћење броја опорављених у односу на укупан број регистрованих случајева (не активних!). Конкретно, уколико дати однос достигне $1-1 / \mathrm{R} 0$, дати тренутак се може сматрати врхунцем епидемије по укупном ठроју потврђених случајева за дате мјере, а и може се очекивати да се Rt симултано снизио значајно испод 1. Формално, оцјена важи за ситауције када је сваки заражени регистрован. Уколико то није случај, јасно је, могуће су грешке. Ипак, када се немају при руци друга средства (нпр. квалитет података није довољан, тестирање није довољно масовно и добро усмјерено, или пак нешто треће), оцјена се може користити за грубе процјене. Под претпоставком да вирус слободно циркулише (у великом броју случајева се не може успоставити јасна епидемиолошка веза новопотврђених случајева) и да су многи асимптоматични преносиоци заразе уједно и нерегистровани опорављени, користићемо поменуту оцјену. 
Послије вијести о ширењу заразе, те предузимању одређених мјера поденцијал заразе слаби, тj. R-вриједност уопштено опада. Штавише, R0 није исти за урбана и рурална подручја.

Према Sanche et al. (2020) новодобијена вриједност R0 je 5,7, што је изузетно висока вриједност. Ипак, дати број одговара Вухану (Кина), граду од 11 милиона становника, у ситуацији када се према званичним подацима мјесец дана није знало за постојање новог вируса CAPC-КоB-2, те је ширење заразе било неометано. Због тога можемо сматрати да дата оцјена вјероватно није примјењива на наше подручје (мањи степен урбанизације) и нашу ситуацију (одређене епидемиолошке мјере су благовремено предузете).

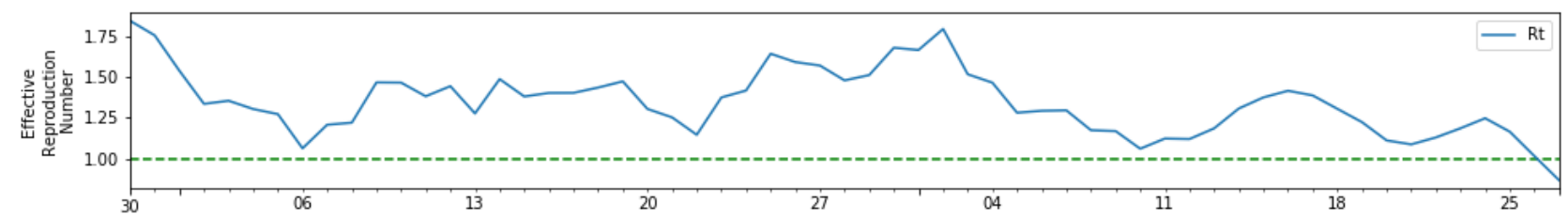

Слика 1: Понашање вријеgносӣи Rt.

Процјену понашања вриједности Rt вршимо према методологији Cori et al. (2013), jep нису доступни сви подаци Института за јавно здравство и Штаба за ванредне ситуације. Методологија Cori et al. (2013) омогућује добру процјену понашања Rt и са опскурнијим подацима. ${ }^{2}$ Приказ понашања вриједности Rt је дат на Слици 1.

Напомена 1. Rt није R0 - основни репродуктивни број којим се оцјењује потенцијал заразе,

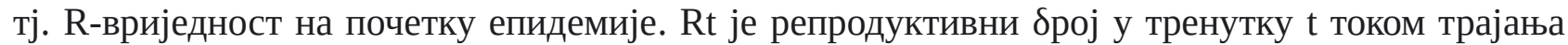

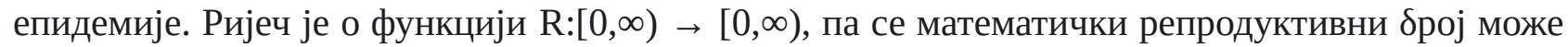
записати исправније као $\mathrm{R}(\mathrm{t})$, за $\mathrm{t}$ из $[0, \infty)$.

За тежинску функцију w(s) је коришћена PMF дискретне геометријске расподјеле, при чему је параметар $\mathrm{p}=0,5$ (средина домена, y немогућности боље процјене). За R0 y прорачуну (као иницијална вриједност од које се креће) узето је 5,7 из Sanche et al. (2020). Добијене вриједности су уравнотежене тродневним просјеком.

Као што се може видјети, вриједност Rt лагано опада, без обзира на ублажавање мјера, што може да укаже на њихову адекватност. Посљедња процјена даје да је Rt $=0,55$, али moving average диже вриједност на 0,86. Очекивати је да је у овом тренутку Rt мало око 0.7.

Напомена 2. Приликом коришћења методологије из Cori et al. (2013) узето je да je R0 = 5,7, али методологија и тродневни просјек указују да је за наше подручје вјероватнији R0 = 1,86 (Слика 1, лијеви крај интервала).

Напомена 3. Један од могућих разлога за падање Rt, односно за блажу епидемиолошку слику је и претпоставка о слабљењу патогености самог вируса CAPC-КоВ-2, наведена у раду Holland et al. (2020), јер је тиме мање симпотматичних случајева, као и оних који захтјевају хоспитализацију. Да патогеност вируса слаби може посредно да укаже сљедеће ${ }^{3}$ :

- упоређивање међусобног одступања стопа раста за смртне и потврђене;

2 У односу на претходне прорачуне, због примјетног „чешља“ у графичком приказу потврђених, вршено је „пеглање“ тродневним просјеком, а потом се користила наведена методологија. Дати приступ је омогућио да се не користе дугачки прозори, касније, у moving average-y.

3 Слабљење патогености не значи само да се слабије мутације вируса шире. Она може бити и резултат „пумпања имунитета“ грађана због избијања епидемије (имунолошко прилагођавање траје око 21 дан), или пак нечег другог (долазак топлијих дана). 
- трендови броја случајева са тежом клиничком сликом у односу на потврђене;

- понашање просјека и медијане смртних случајева у односу на очекиван животни вијек;

- понашања просјека и медијане за дужину болничког лијечења;

- тренд пораста броја инфицираних који током цјелокупног периода инфекције не показују никакве симптоме. ${ }^{4}$

\section{2 Завршетак епидемије унутар постојећих мјера}

Појам врхунац (екстрем) може да има више значења с обзиром на његово математичко значење. Конкретно, у разумијевању епидемиолошке ситуације имамо:

- врхунац броја потврђених случајева на дневној бази (4. мај са 69 потврђених)

- врхунац броја активних случајева (8. и 16. мај са по 598 активних случајева)

- укупан број потврђених случајева током трајања епидемије (крај епидемије)

- врхунац смртних случајева на дневној бази (8. мај са 8 смртних случајева)

- укупан број смртних случајева (крај епидемије).

Листа се може проширивати посматрајући различите параметре.

Користећи оцјену $1-1 / \mathrm{R} 0$, за R0 = 1,86, на данашњи дан процјена говори да ће завршетак епидемије - укупан броја случајева током епидемије - бити за 12 дана, тј. око 8. јуна. ${ }^{5}$ Процјена је урађена помоћу оруђа FBprophet (погледати Taylor and Letham (2018)), подразумјевајући логистички раст вриједности и приказана на Слици 2.

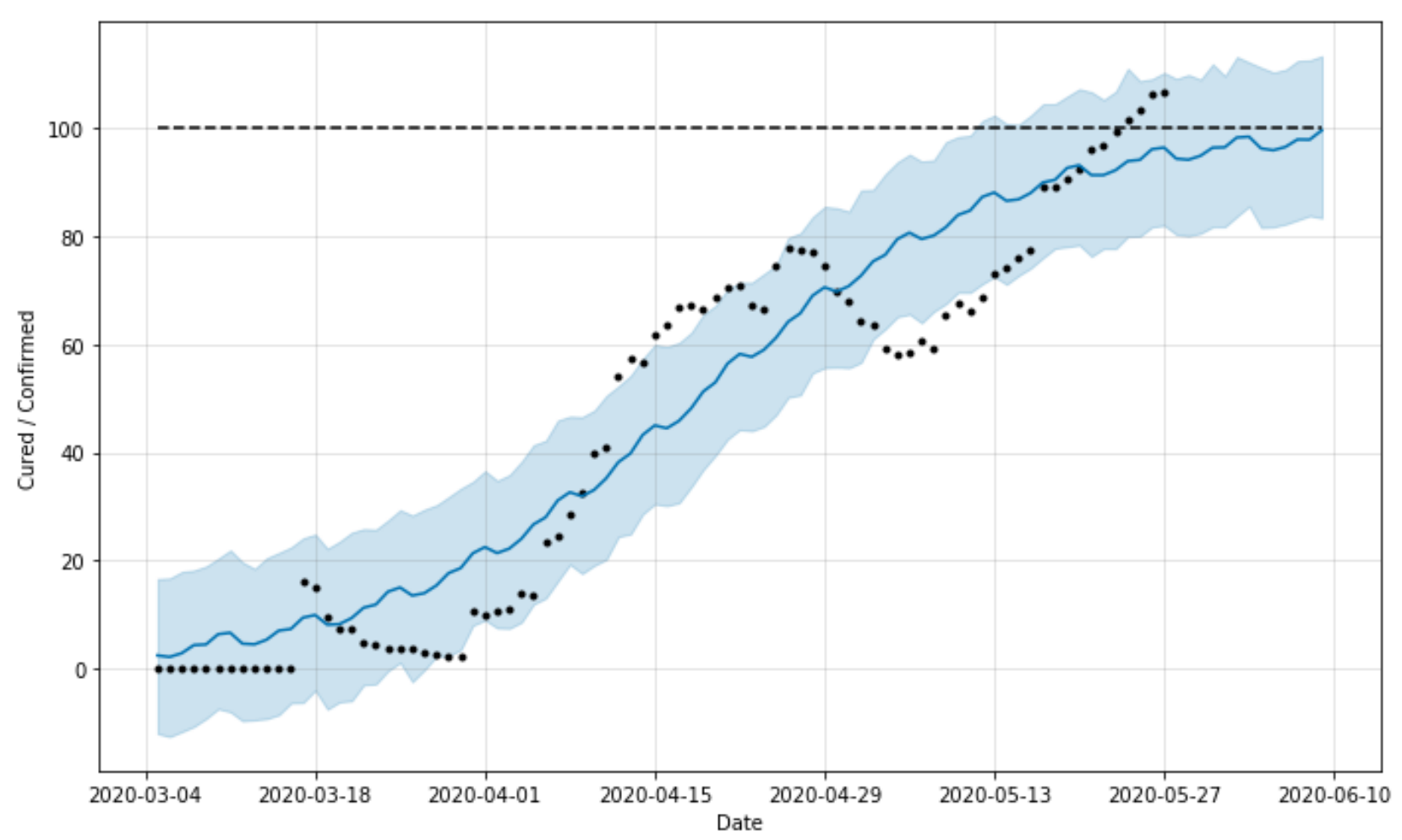

Слика 2: Процјена завршетка епидемије.

4 Термин асимптоматичан се односи како на заражене који у датом тренутку не испољавају симптоме болести, али касније се јаве симптоми обољења, тако и на оне који који заразу изнесу „на ногма“, ни не осјетивши је.

5 Претходна предвиђања су указивала на датуме 17. и 9. јун. Помијерање датума говори о убрзаном побољшању епидемиолошке ситуације. 
Примједба 1. Завршетак епидемије унутар постојећих мјера би, у суштини, значио би да јављање спорадичних случајева послије 8. јуна, а при текућим мјерама, не би било статистички значајно.

Примједба 2. Према Слици 2, однос опорављених и потврђених већ је прешао постављену границу $1-1 / \mathrm{R} 0$, тако да би завршетак епидемије можда могао бити и раније.

Примједба 3. Завршетак епидемије унутар постојећих мјера не значи да би са здравственог становишта била дозвољена масовна окупљања послије 9. јуна. Процјену стања што се тога тиче може да да здравствени епидемиолог, а не математичар-епидемиолог.

Напомена 4. Ријеч карантин означава 40 дана и користио се у 14. и 15. вијеку међу Млецима, а означавао је период изолације бродова прије него што би путници или посада могли изаћи вани током епидемије Црне смрти (куге). Карантину је претходио trentino - 30-дневна изолација, први пут наметнута 1347. године у Дубровнику. У данашње вријеме би се моїло сматрати да датом периоду одговара максимални период инкубације (без аутлајера), по посљедњем регистрованом случају.

\section{3 Процјена кретања потврђених и активних случаја}

Процјена броја потврђених случајева је дата на Слици 3. У предвиђању је коришћено оруђе FBprophet, а горња граница је процјењена на основу best fit-a за посљедњих 7 дана, узимајући у обзир заокруживање вриједности граница на 50. Очекује се да ће број потврђених случајева бити испод $1500 .^{6}$

На Слици 4 приказана је процјена модификованом метологијом. Због промјена у мјерама, промјене саме динамике епидемије (почетак није исто што и крај), те због примједби о слабљењу патогености вируса, за предвиђање на краћи период се могу користити и подаци са краћом историјом. Другим ријечима, процјена максималног броја реі̄исӣрованих заражених користећи 14-дневну историју је мања од 1500. И овај поглед на ситуациу указује да се ствари убрзано одвијају у повољном смијеру.

Што се тиче понашања броја активних случајева, коришћен je best fit Гаусове функције, при чему је врхунац одређен према доступним реалним подацима. Конкретно, претпоставка је да аномалија послије 27. априла има врхунац 8. маја, који се поновио још 16. маја. Стога, за формални врхунац Гаусове криве узет је средњи датум између посљедња два, тј. 12. мај. Резултати уклапања су приказани на Слици 5.

Примједба 4. Послијеваскршња аномалија захтјева одређену допунску анализу. Епидемиолошки би се могло утврдити да је до скока дошло повезивањем са мјестом боравка поменутих случаја, но према јавно доступним подацима није се утврдила епидемиолошка веза са прославом Васкрса.

Примједба 5. Гаусова крива не одговара уобичајеним расподјелама броја активних случајева. За процјену кретања бројева, како потврђених, тако и активних и опорављених се користе

6 Предвиђање урађено 19. маја је говорило о горњој граници од 1600 потврђених случајева, што такође говори да се епидемиолошка слика побољшава. 
SEIR модели (најчешће проширени SEIR модел), чија крива активних случаја подсјећа на „звонасту“ Гаусову.

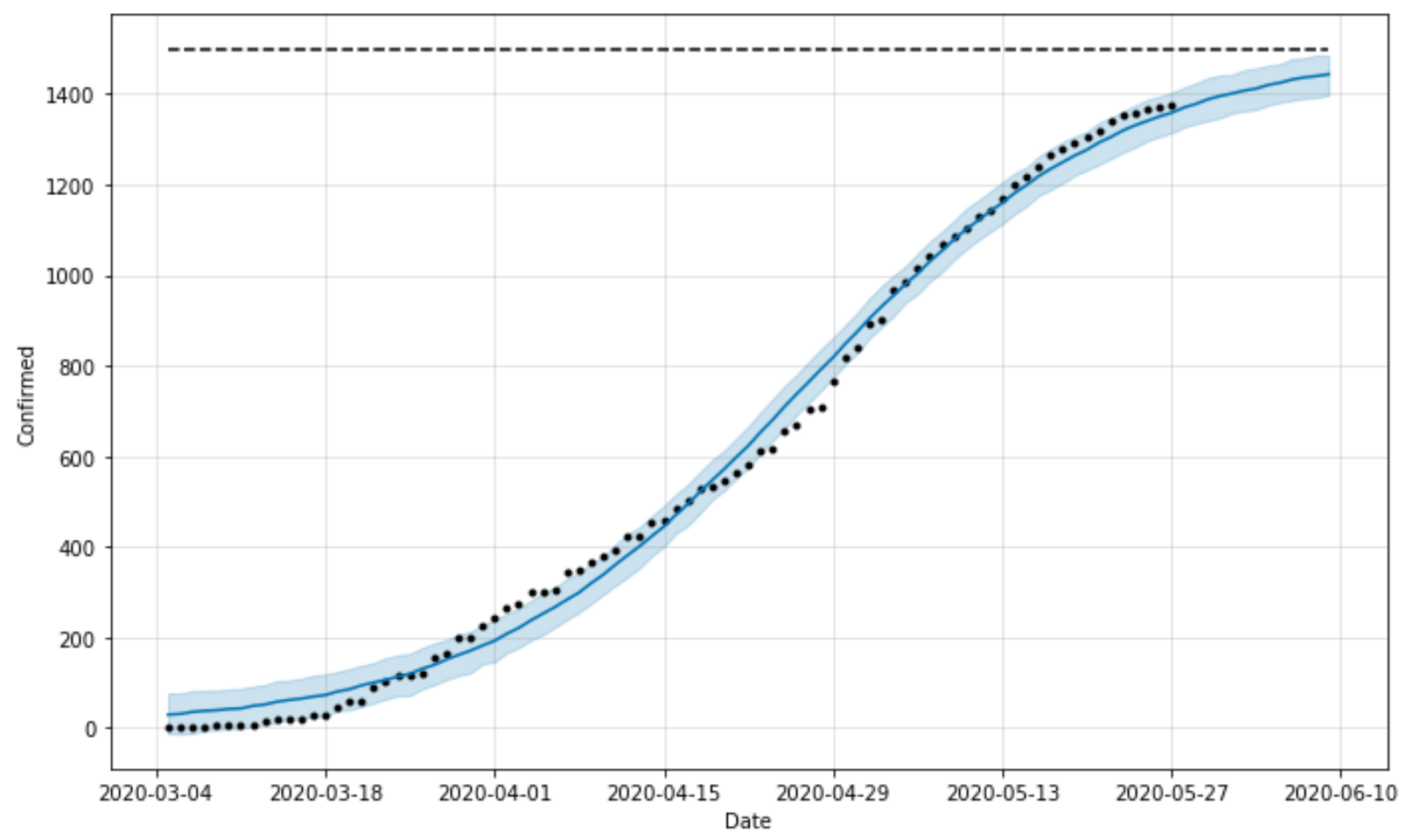

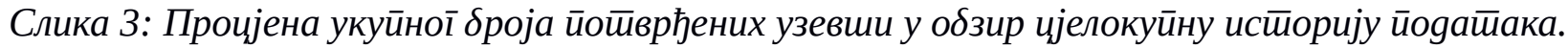

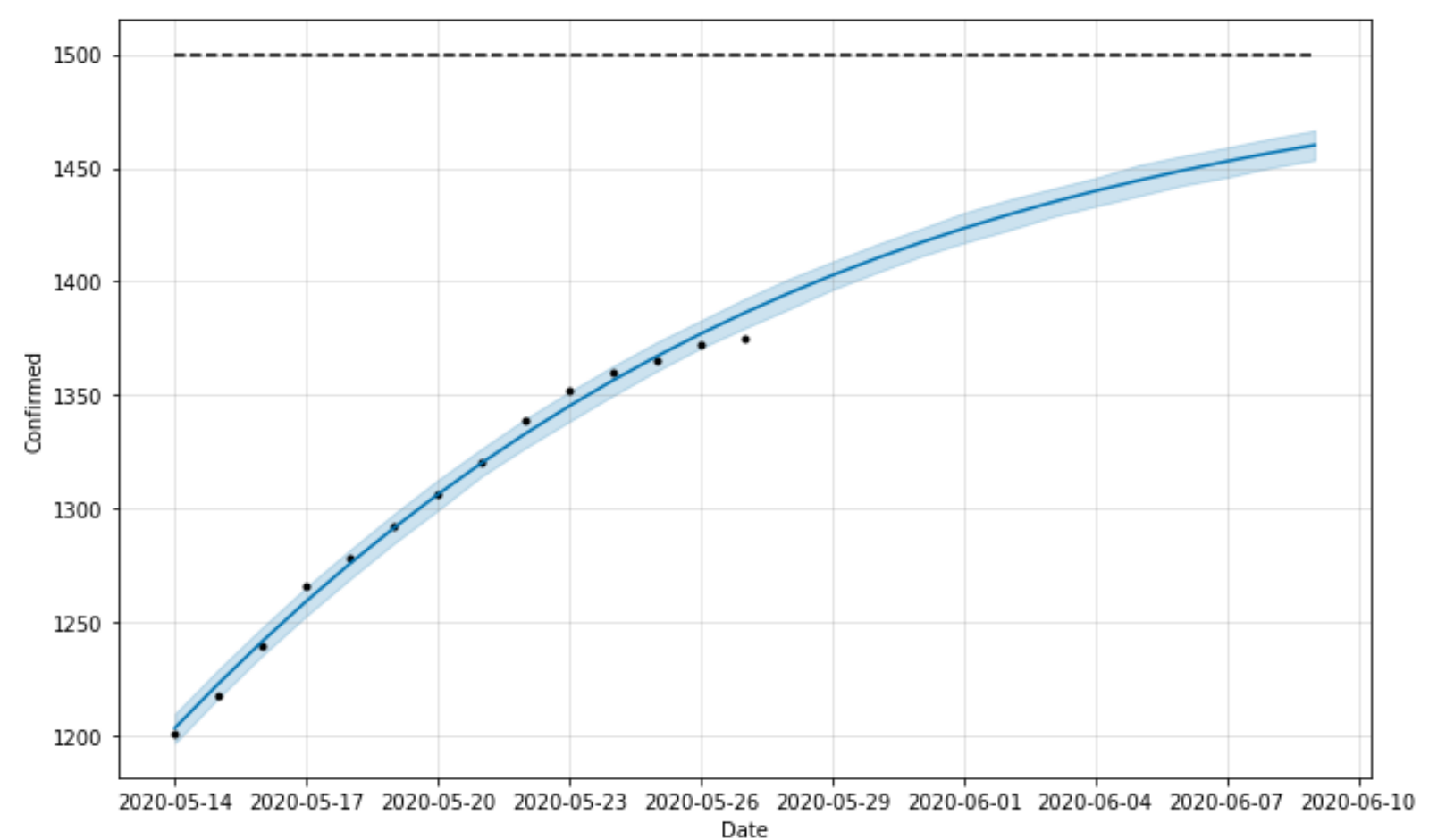

Слика 4: Процјена укуйної броја ӣоӣврђених на основу ӣосљеgњих 14 gана. 
Сходно посљедњој примједби, Гаусова крива је коришћена за процјену из три разлога:

1. лакше је извршити „уклапање“, јер је функција позната, а криве SEIR модела настају рјешавањем система диференцијалних једначина;

2. користили су је за грубе процјене ситуације у региону и свијету;

3. постојање послијеваскршње аномалије.

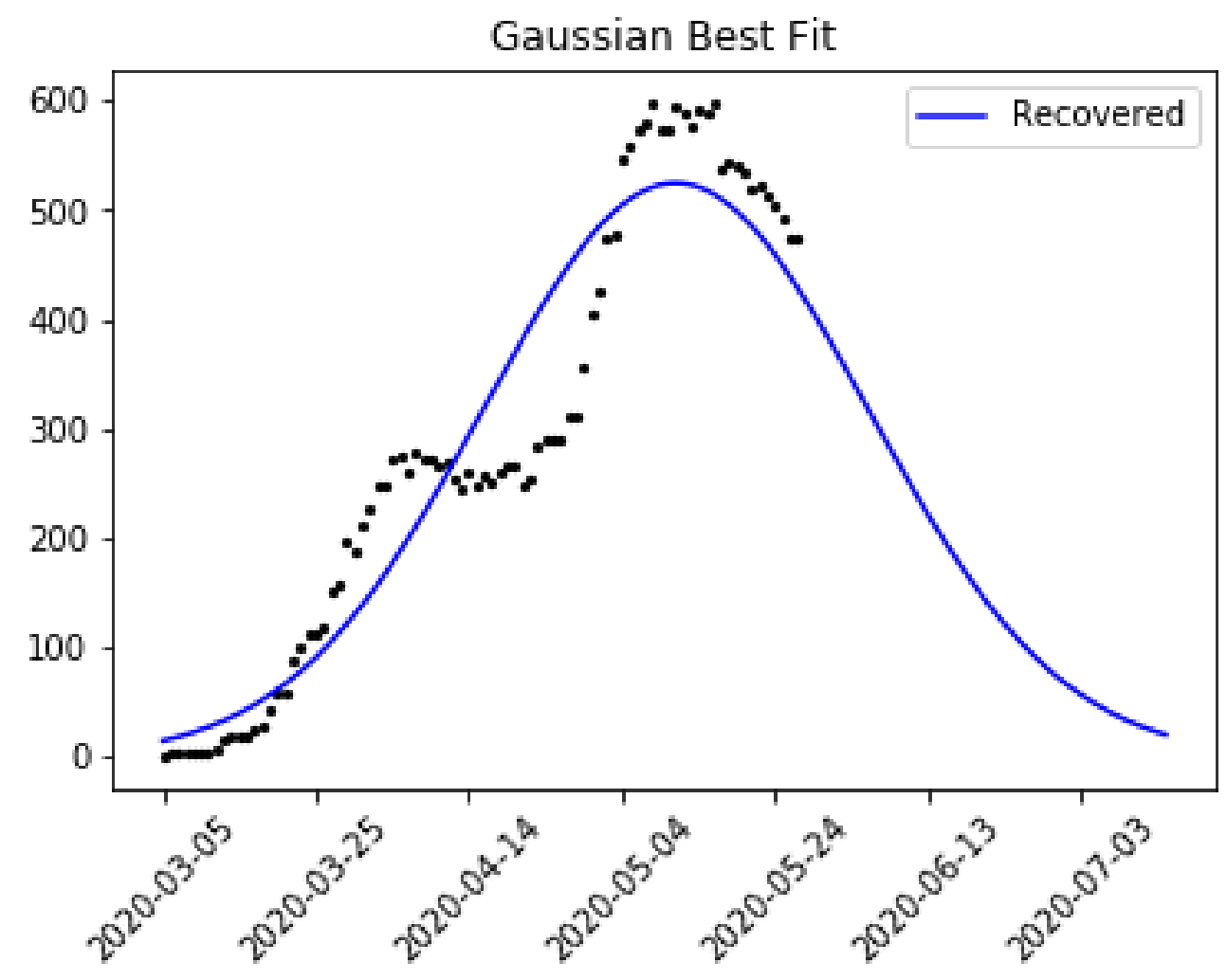

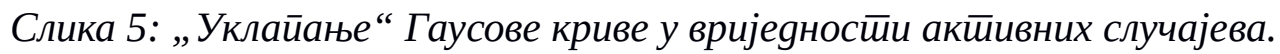

Напомена 5. Број активних случајева бива већи од 0 и по завршетку епидемије, јер се односи на оне који су под надзором или који се лијече, иако нема више новопотврђених.

\section{4 Смртност}

Једна од грубих оцјена за укупан број смртних случајева је множење броја смртних до оцијењеног врхунца са два. Према садашњој ситуацији, имамо 77 смртних случајева укупно на дан 12. мај, што даје оцјену од око 154 смртних случајева укупно током трајања епидемије. Постоји оправдана могућност да се смртност смањи, јер се очекује слабљење патогености вируса, као и одређено побољшање у број опорављених, с обзиром на добијена сазнања о могућим третманима. Конкретно, имамо сљедеће радове:

- Улога витамина Д у превенцији вирусом CAPC-KoB-2 (Ilie et al., 2020)

- Третирање заражних САРС-КоВ-2 вирусом захтјева узимање допунских количина цинка (Shitu and Afolami (2020)) 
- Nicotianamine из соје може да помогне у третирању заражених CAPC-КоB-2 вирусом (Chen and Du (2020))

- „Преквалификација“ лијекова за третирање заражених CAPC-KoB-2 (Gordon et al., 2020)

Максимална смртност би могла да буде око 13\% на крају епидемије за постојеће мјере (Слика 6). ${ }^{7}$ Вриједност је добијена узевши у обзир логистички тренд и помак од 7 дана уназад за потврђене случајеве (људи који су преминули данас заразили су се неколико дана раније, а неки и више од двије седмице раније).

С друге стране, трендовска процјена говори да би смртност трељала да буде око 7,5\% на њеном крају при постојећим мјерама (Слика 7). ${ }^{8}$ Вриједност је добијена процјеном тренда односа преминулих и затворених случајева.

На данашњи дан број смртних случајева 108, а претпоставка да број потврђених не $\delta и$ требао значајно да пређе 1450 , даје проценат од 7,45\%, што говори да у наредном периоду није очекивано неко повећање смртних случајева, бар не статистички значајно. Имајући у виду грубу процјену од 154 смртна случаја, може се примијетити да је до краја епидемије трендовска процјена мања за око 30\% од груঠе.

Реалистичнија процјена би требала бити између грубе и трендовске. Узимајући у обзир цјелокупну историју података добијамо 131 смртни случај (Слика 8). С друге стране, на основу података у посљедњих 14 дана добијамо процјену од 122 смртна случаја (Слика 9).

Напомена 6. Проценат добијен Time Series Forecasting-ом не узима у обзир процјену потврђених случајева, активних случајева, и текући број преминулих. Ријеч је о „хватању“ тренда и периодичности.

\section{5 Закључак}

На основу посљедњих података који су јавности предочени путем сајта koronavirususrpskoj.com и сајта covid19.etfbl.net процијењено је стање у Републици Српској, коришћењем оруђа FBprophet и пакета scipy, pandas, и matplotlib. Ријеч је о простијим програмским оруђима за вршење одговарајућих статистичких предвиђања. Угрубо, очекује се постепено јењавање заразе и њено лагано ишчезавање при постојећим мјерама. Према

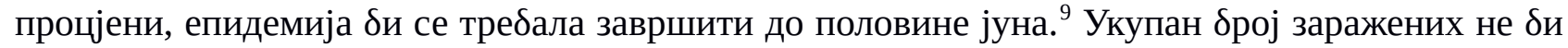
требао значајно прећи 1400, а смртност би требала да лагано пада и буде нешто испод 10\% на

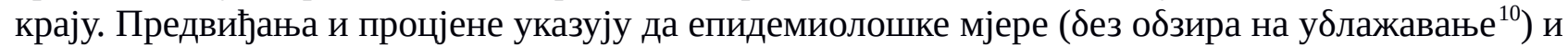
индиковано слабљење патогености вируса побољшавају текућу ситуацију. Допунско ублажавање мјера ствара нову ситуацију за коју можда не би важила више ова анализа.

7 За 19. мај је процјена максималне смртности била 14\%, што такође говори о побољшању епидемиолошке ситуације.

8 За 19. мај је реалистичнија процјена смртности била 5\%, али је уједно и ријеч о дужем процијењеном трајању епидемије те се захваћеним трендом смањења проценат спушта ниже. Ипак, у односу на процјену од 23. маја, процјена смртности је порасла са 6\% на 7,5\%.

9 На 19. мај се процјена односила на другу половину јуна. На 23. мај се односила на вријеме до половине јуна.

10 У патогености. 


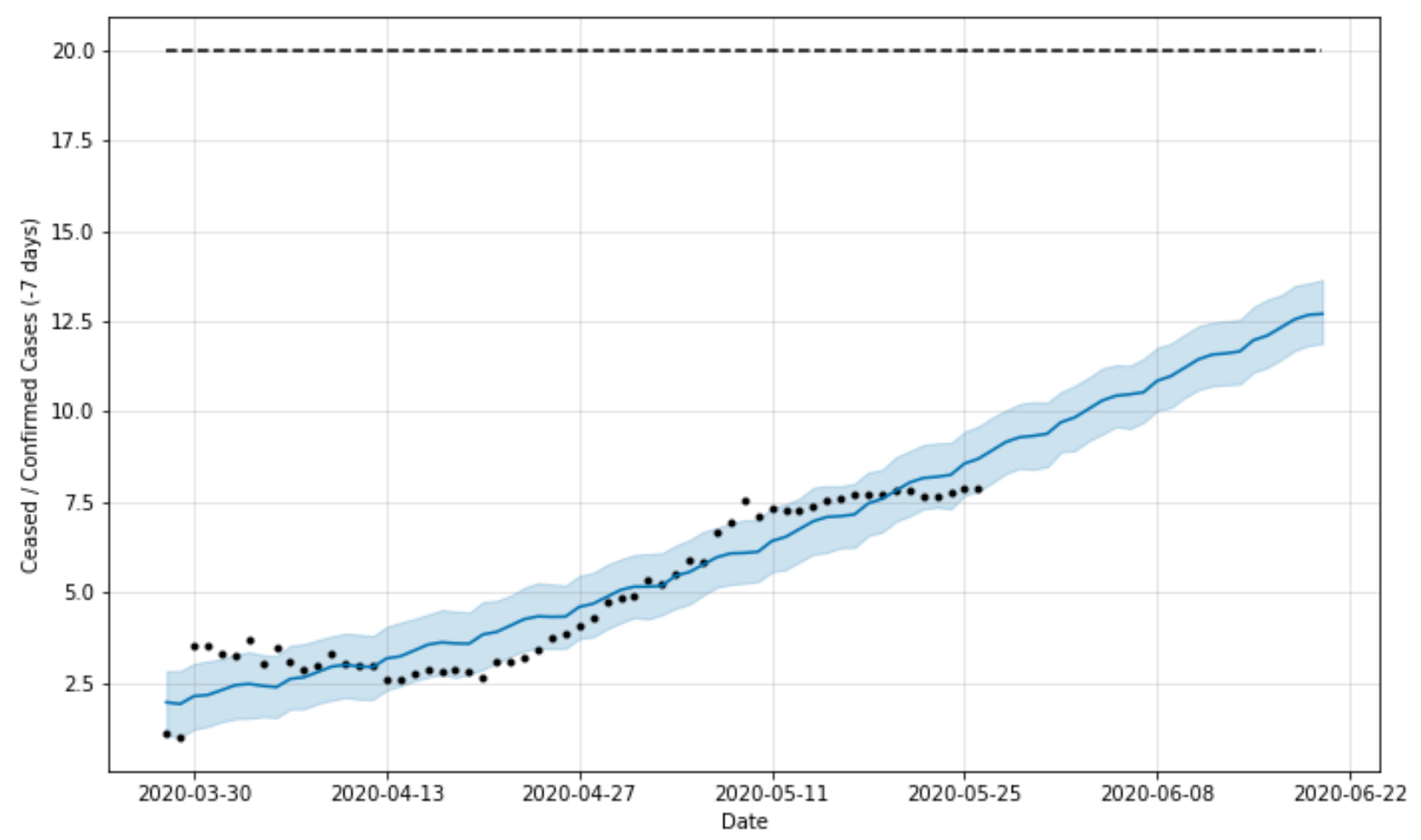

Слика 6: Трендовска процјена максималне стопе смртности.

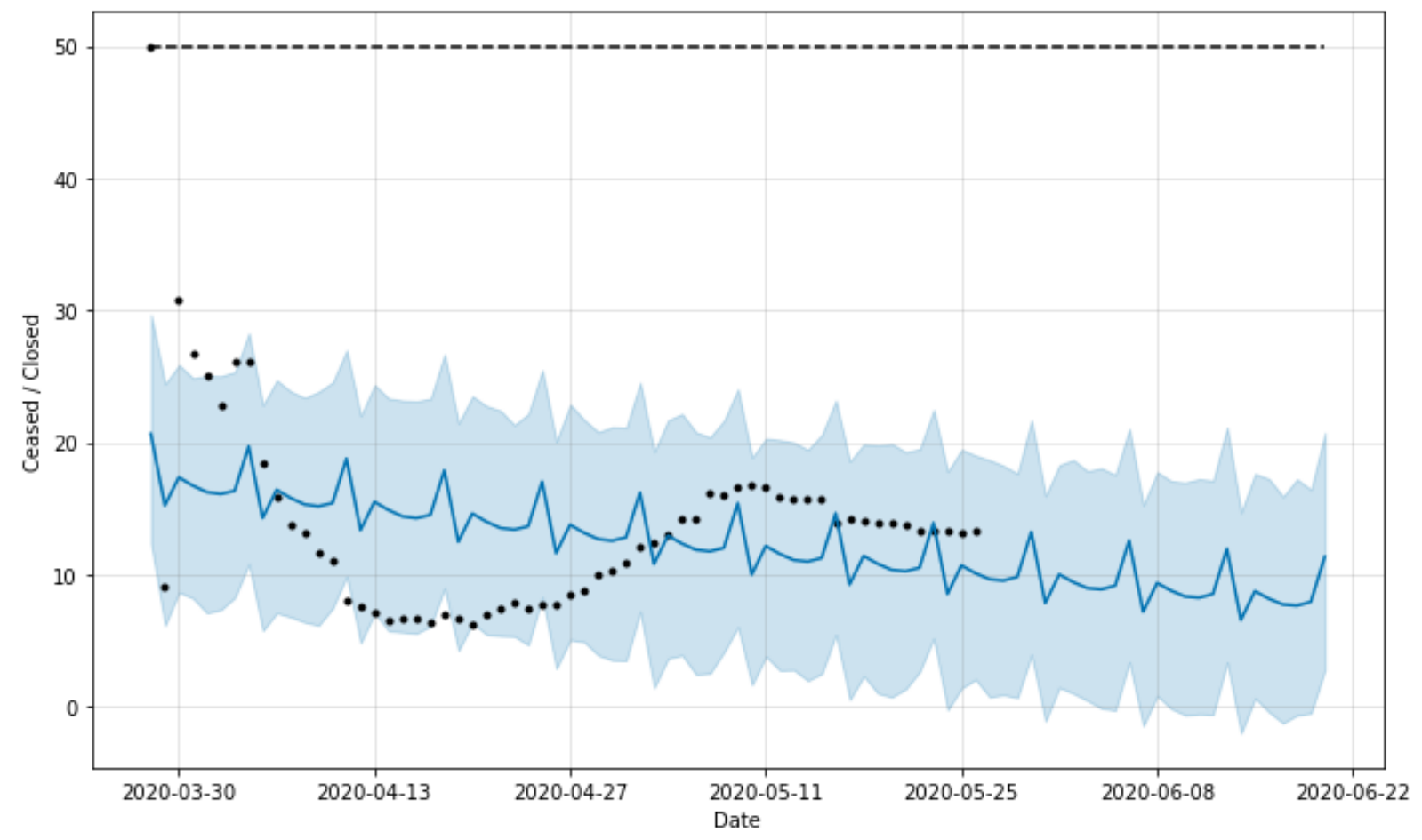

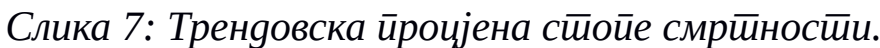




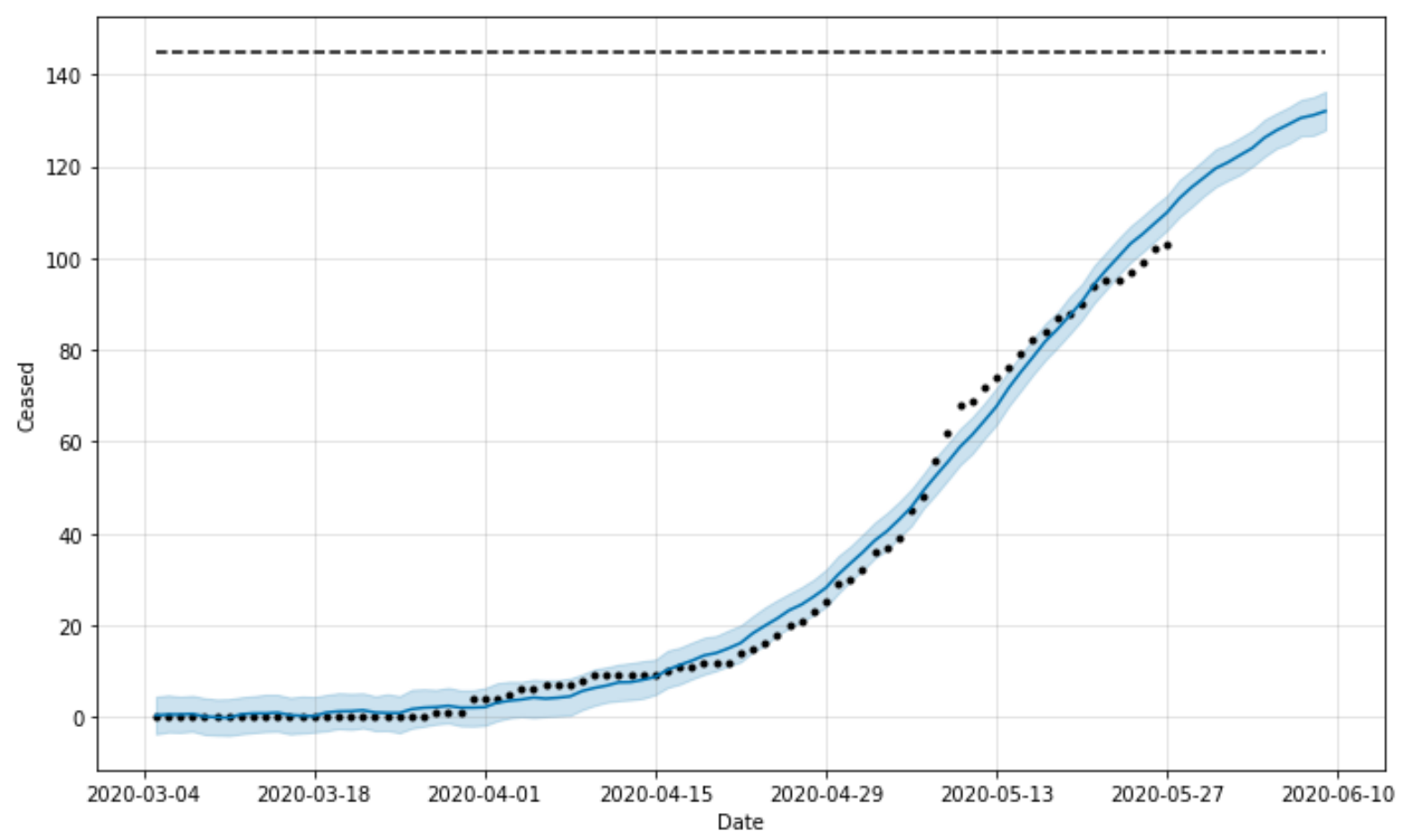

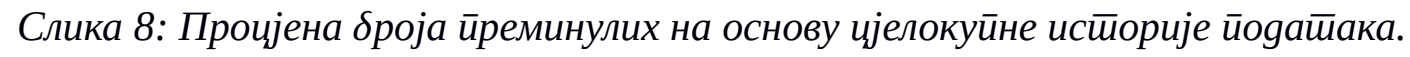

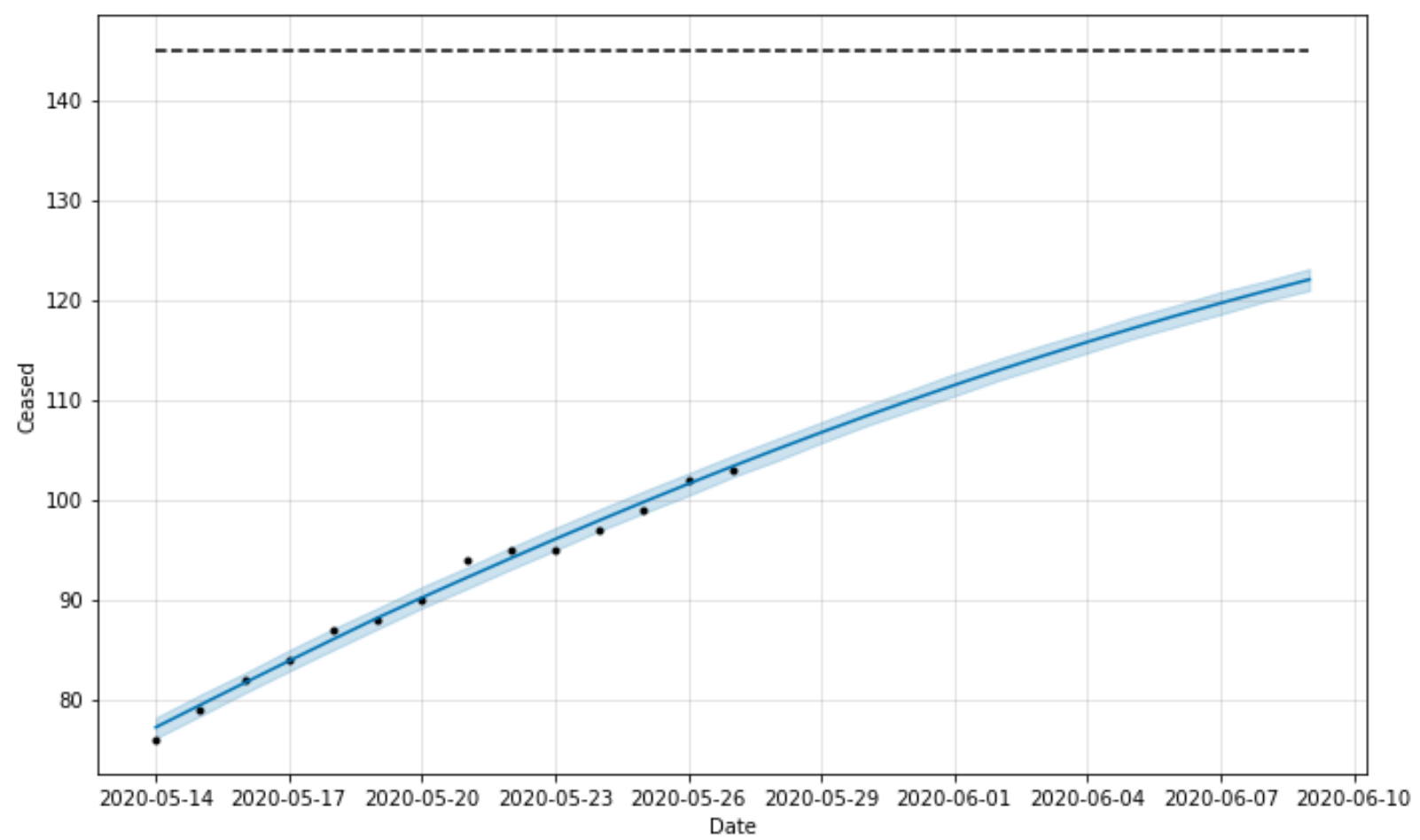

Слика 9: Проџјена броја ӣреминулих на основу ӣосљеgњих 14 gана. 


\section{Литература}

1. Cori A, Ferguson N, Fraser C, Cauchemez S. A New Framework and Software to Estimate Time-Varying Reproduction Numbers During Epidemics. American Journal of Epidemiology 178(9):1505-1512 (2013) https://doi.org/10.1093/aje/kwt133

2. Chen H, Du Q. Potential Natural Compounds for Preventing SARS-CoV-2 (2019-nCoV) Infection. Preprints 2020, 2020010358 (doi: 10.20944/preprints202001.0358.v3)

3. Gordon, D. E. et al. A SARS-CoV-2 protein interaction map reveals targets for drug repurposing. Nature https://doi.org/10.1038/s41586-020-2286-9 (2020).

4. Hunter J. Matplotlib: A 2D Graphics Environment, Computing in Science \& Engineering, 9, 90-95 (2007), DOI:10.1109/MCSE.2007.55

5. Holland L, Kaelin E, Maqsood R, Estifanos B, Wu L, Varsani A, Halden V, Hogue B, Scotch M, Lim E. Journal of Virology JVI.00711-20 (2020) doi: 10.1128/JVI.00711-20

6. Ilie P.C., Stefanescu S. \& Smith L. The role of vitamin D in the prevention of coronavirus disease 2019 infection and mortality. Aging Clin Exp Res (2020). https://doi.org/10.1007/s40520-020-01570-8

7. McKinney W. Data Structures for Statistical Computing in Python, Proceedings of the 9th Python in Science Conference, 51-56 (2010)

8. Sanche S, Lin YT, Xu C, Romero-Severson E, Hengartner N, Ke R. High contagiousness and rapid spread of severe acute respiratory syndrome coronavirus 2. Emerg Infect Dis. 2020 Jul. https://doi.org/10.3201/eid2607.200282

9. Virtanen et al. (2020) SciPy 1.0: Fundamental Algorithms for Scientific Computing in Python. Nature Methods, in press.

10. Shittu M, \& Afolami O. Improving the efficacy of Chloroquine and Hydroxychloroquine against SARS-CoV-2 may require Zinc additives - A better synergy for future COVID-19 clinical trials. Le infezioni in medicina: rivista periodica di eziologia, epidemiologia, diagnostica, clinica e terapia delle patologie infettive, 28(2):192-197 (2020)

11. Taylor S and Letham B. Forecasting at scale. Amer. Statistician 72(1):37-45 (2018) 